\title{
Aloe vera (Aloe Barbadeenis Mill) screens at suitable salinity and sodicity level
}

\begin{abstract}
Salinity limits the growth, exchange and production of plants growth of Aloe Vera (Aloe barbadeenis Mill). This experiment was conducted to remind the effects of $\left(4 \mathrm{dSm}^{-1}+13.5\right.$ $\left(\mathrm{mmol} \mathrm{L}^{-1}\right)^{1 / 2}, 5 \mathrm{dSm}^{-1}+25\left(\mathrm{mmol} \mathrm{L}^{-1}\right)^{1 / 2}, 5 \mathrm{dSm}^{-1}+30\left(\mathrm{mmol} \mathrm{L}^{-1}\right)^{1 / 2}, 10 \mathrm{dSm}^{-1}+25\left(\mathrm{mmol} \mathrm{L}^{-1}\right)^{1 / 2}$ and $\left.10 \mathrm{dSm}^{-1}+30\left(\mathrm{mmol} \mathrm{L}^{-1}\right)^{1 / 2}\right)$ on biomass yield of Aloe Vera. $4 \mathrm{dSm}^{-1}+13.5\left(\mathrm{mmol} \mathrm{L}^{-1}\right)^{1 / 2}$ treatment attained maximum biomass yield $\left(153.33\right.$ gpot $\left.^{-1}\right)$. Biomass produce was reduced with the increase of the salts toxicity. Minimum biomass yield $\left(98.10\right.$ gpot $\left.^{-1}\right)$ was produced at $10 \mathrm{dSm}^{-1}+30\left(\mathrm{mmol} \mathrm{L}^{-1}\right)^{1 / 2} \cdot 5 \mathrm{dSm}^{-1}+25\left(\mathrm{mmol} \mathrm{L}^{-1}\right)^{1 / 2}$ treatment exhibited improved outcome i.e. the least diminution \% over control (9.99). Salinity- sodicity showed staid effect on the growth reduction from $9.99 \%$ to $36.02 \%$. This reduction fissure was impacted by the harmful effect of salinity and sodicity on coriander growth. Salinity- sodicity behaved toxic impact on the growth reduction from $9.99 \%$ to $36.02 \%$. Based on the findings, Aloe Vera (Aloe barbadeenis Mill) was able to grow better at $4 \mathrm{dSm}^{-1}+13.5\left(\mathrm{mmol} \mathrm{L}^{-1}\right)^{1 / 2}$ treatment.
\end{abstract}

Keywords: aloe vera (Aloe barbadeenis mill), saline- sodic, medicinal value and biomass yield
Volume 2 Issue 6 - 2018

\author{
Muhammad Arshad Ullah,' Muhammad \\ Rasheed, ${ }^{2}$ Imdad Ali Mahmood' \\ 'Land Resources Research Institute, National Agricultural \\ Research Centre, Pakistan \\ 2PMAS - Agronomy Department, University of Arid Agriculture, \\ Pakistan
}

\begin{abstract}
Correspondence: Muhammad Arshad Ullah, Land Resources Research Institute, National Agricultural Research Centre, Islamabad, Pakistan, 45500, Email arshadallah1965@gmail.com
\end{abstract}

Received: October 10,2018| Published: December 06, 2018

\section{Introduction}

In waterless areas saline stress is one of the sternest off-putting factors for plant growth and yield. According to ${ }^{1}$ approximately $23 \%$ of the world's cultivated lands is saline while sodic is $37 \%$. Extensive worldwide research was conducted to investigate the impact of salinity on plant growth and produce of various plant species. ${ }^{2-9}$

Being the best medicinal herb, The Aloe plant has a shocking sum of excellent research concerning its benefits which are not alike of to many other herbs. Reticent people or who have no entrance to medical support mostly use medicinal plants as medicines. For the Bacterial and fungal infections, and stomachache and toothache were treated with geranium of rose-scented and lemon grass respectively in Algeria. Thus, numerous experiments have been published whose endeavor of the organic or aqueous extracts of these plants was to appraise the anti-inflammatory activity either on in vitro human or on in vivo rodents. ${ }^{10,11}$ Medicinal and scented plants are benefitted for diverse purposes as a result of their dynamic components. ${ }^{12}$ However, environmental conditions strongly influence the quality and the quantity of secondary metabolites of medicinal plants. Different studies have been carried out to obtain high produce genotypes of these plants about response of medicinal and aromatic plants against the salinity stress under different environmental conditions, in. ${ }^{13}$ Productivity of crop plants considered definitely salinity stress as one of the most serious environmental limiting factors. Due to this reality the salts disturbs the plant physiology, growth and development aspects. ${ }^{14}$ In the middle of the $21^{\text {st }}$ century $50 \%$ of arable land will be affected by salinity. ${ }^{15}$ Seed priming is a pre-sowing treatment that that limits hydration to involve the disclosure of seeds with low external water potential. This technique is a very useful seed treatment that can boost emergence, growth, yield and salt tolerance mainly under unfavorable environmental conditions. Different growth stages of physiological life of medicinal plants have severely affected by salt stress. Seed germination under saline environment is one of the most important parts of plant life. $\left.{ }^{16} \mathrm{FAO}(2000)\right)^{17}$ reported that about $20 \%$ of the world's cultivated land and approximately half of all irrigated land and $2.1 \%$ of the dry agriculture land is affected by salinity. Due to wrong management of irrigation and drainage salt effectiveness is increasing more hastily in irrigated lands. Besides, rain, cyclones and wind add $\mathrm{NaCl}$ to coastal agricultural lands. ${ }^{18}$ The fast raise in the world's population needs an increase in cultivated areas to elevate food. Salinity faces severe ecological troubles that disturb lowland cover and the supply of animal feed in arid and semiarid zones. Guar is contemplated as a non-thirsty crop considering drought tolerance potential. ${ }^{19}$ Guar grows sound under a broad array of soil conditions together with alkalinity, salinity and low soil fertility. ${ }^{20}$ Guar's response to soil salinity stress examined the relationship between the root system and salt tolerance in 15 guar accessions. ${ }^{21}$ Growth and productivity of plants is seriously impacted by salinity being the major abiotic limiting stress. ${ }^{22}$ One-third of the irrigated land on earth marks salinity. ${ }^{23,24}$ Food production lost due to such stress crates awareness to the importance of plant breeding aspect to introduce salt tolerance for future prospect of the food requirement worldwide specially arid and semi- arid zones. ${ }^{25}$ Researchers have done a lot of work on salinity stress tolerance using molecular and physiological mechanism but we have to do more for the development of salt tolerance genotypes rapidly. ${ }^{26}$ Plant tissues having excessive levels accumulation of $\mathrm{Na}+$ ion one of the key factors inducing salinity damage. ${ }^{25,27}$ Correlation of salinity tolerance of crops is significant with $\mathrm{Na}+$ exclusion ability. ${ }^{28,29,30}$ Mechanism of salt tolerance is mainly concerned with different growth stages. However, differences in salinity tolerance causes with the growth stage are not done properly yet. ${ }^{29}$

\section{Materials and methods}

A pot experiment was planned to assess the salinity tolerance of medicinal plant Aloe Vera (Aloe barbadeenis Mill) with various saline and sodic levels in green house of Land Resources Research Institute, National Agricultural Research Centre, Islamabad, Pakistan during, 2017. The physiochemical properties of soil used for the pot experiment were; $\mathrm{pH}=7, \mathrm{ECe}=1.8\left(\mathrm{dSm}^{-1}\right), \mathrm{SAR}=4.7\left(\mathrm{mmol} \mathrm{L}^{-1}\right)^{1 / 2}$, Saturation Percentage $=21.2(\%)$, O.M. $=0.41(\%)$, Available P=7.2 (mg $\left.\mathrm{Kg}^{-1}\right)$ and Extractable $\mathrm{K}=97.7\left(\mathrm{mg} \mathrm{Kg}^{-1}\right)$. Keeping in view the pre- 
sowing soil analysis, the different combinations of ECe (Electrical conductivity) and SAR (Sodium Absorption Ratio) were artificially developed with salts of $\mathrm{NaCl}, \mathrm{Na}_{2} \mathrm{SO}_{4}, \mathrm{CaCl}_{2}$ and $\mathrm{MgSO}_{4}$ using Quadratic Equation. $10 \mathrm{Kg}$ soil was filled in each pot. 10 seeds of Aloe Vera (Aloe barbadeenis Mill) were sown in each pot. Fertilizer was applied @ 50-45-40 NPK Kg ha ${ }^{-1}$. Treatments were; $\left(4 \mathrm{dSm}^{-1}+13.5\right.$ $\left(\mathrm{mmol} \mathrm{L}^{-1}\right)^{1 / 2}, 5 \mathrm{dSm}^{-1}+25\left(\mathrm{mmol} \mathrm{L}^{-1}\right)^{1 / 2}, 5 \mathrm{dSm}^{-1}+30\left(\mathrm{mmol} \mathrm{L}^{-1}\right)^{1 / 2}$, $10 \mathrm{dSm}^{-1}+25\left(\mathrm{mmol} \mathrm{L}^{-1}\right)^{1 / 2}, 10 \mathrm{dSm}^{-1}+25\left(\mathrm{mmol} \mathrm{L}^{-1}\right)^{1 / 2}$ and $10 \mathrm{dSm}^{-}$ ${ }^{1}+30\left(\mathrm{mmol} \mathrm{L}^{-1}\right)^{1 / 2)}$. Completely randomized deign was applied with three repeats. Biomass yield was collected. Statistically analysed data means were compared at $5 \%$ probability level (Montgomery, 2001).

\section{Results and discussions}

Extreme salinity reduces the proficiency of several plants with different irregular morphological, physiological and biochemical changes that delay germination, high seedling transience, poor plant population, diminutive growth and lower yields. Biosaline agriculture (utilization of these salt- affected lands without disturbing present condition) is an economical way to use the salt- affected soils and bring this area under cultivation. Considering these values, a pot study was carried out to assess the salt tolerance of Aloe Vera (Aloe barbadeenis Mill) under different salt concentrations. Significant divergence was initiated with treatments on biomass yield (Table 1). Highest biomass yield (153.33 gpot $\left.{ }^{-1}\right)$ was gained by $4 \mathrm{dSm}^{-1}+$ $13.5\left(\mathrm{mmol} \mathrm{L}^{-1}\right)^{1 / 2}$ treatment. Biomass yield was decreased as well as the toxicity of salts was increased. Minimum biomass yield $(98.10$ gpot $\left.^{-1}\right)$ was produced at $10 \mathrm{dSm}^{-1}+30\left(\mathrm{mmol} \mathrm{L}^{-1}\right)^{1 / 2}$. Osmotic stress and ion toxicity are two major causes of salinity stress. ${ }^{31}$ Low water potential in saline soils induced osmotic stress which prevents water absorption in plant tissues. ${ }^{32,33}$ Stomata closure is associated to avoid water loss, which in sequence decreased the photosynthetic rate and $\mathrm{CO}_{2}$ availability and finally reduced the crop produce. ${ }^{32-34}$ Molecular geneticists and physiologists jointly improved the salinity tolerance..$^{35}$ Table 1 also explained the \% decrease in biomass yield over control. $5 \mathrm{dSm}^{-1}+25\left(\mathrm{mmol} \mathrm{L}^{-1}\right)^{1 / 2}$ treatment performed better results i.e. the least reduction \% over control (9.99). Salinity- sodicity showed serious effect on the growth reduction from 9.99 to $36.02 \%$. This huge fissure was impacted by the negative effect of salinity cum sodicity on Aloe Vera (Aloe barbadeenis Mill) growth. Salinity- sodicity showed staid effect on the growth reduction from 9.99 to $36.02 \%$. This reduction fissure was impacted by the harmful effect of salinity and sodicity on Aloe Vera (Aloe barbadeenis Mill) growth. Salinity- sodicity behaved toxic impact on the growth reduction from 9.99 to $36.02 \%$. Plant physiology, growth and development are mostly disturbed with salt toxicity (Borsani et al. 2003). ${ }^{36-38}$

Table I Effect of various salinity and sodicity levels on biomass yield of Aloe Vera (Aloe barbadeenis Mill) as medicinal crop

\begin{tabular}{|c|c|c|}
\hline Treatments & Biomass yield $\left(\right.$ gpot $\left.^{-1}\right)$ & $\%$ decrease over control \\
\hline $\mathrm{ECe}=4 \mathrm{dSm}^{-1}+\mathrm{SAR}=13.5\left(\mathrm{mmol} \mathrm{L}^{-1}\right)^{1 / 2}$ & I53.33a & ------ \\
\hline $\mathrm{ECe}=5 \mathrm{dSm}^{-1}+\mathrm{SAR}=25\left(\mathrm{mmol} \mathrm{L}^{-1}\right)^{1 / 2}$ & I38.00ab & 9.99 \\
\hline $\mathrm{ECe}=5 \mathrm{dSm}^{-1}+\mathrm{SAR}=30\left(\mathrm{mmol} \mathrm{L}^{-1}\right)^{1 / 2}$ & $133.17 \mathrm{~b}$ & 13.14 \\
\hline $\mathrm{ECe}=10 \mathrm{dSm}{ }^{-1}+\mathrm{SAR}=25\left(\mathrm{mmol} \mathrm{L}^{-1}\right)^{1 / 2}$ & $124.83 \mathrm{~b}$ & 18.58 \\
\hline $\mathrm{ECe}=10 \mathrm{dSm}^{-1}+\mathrm{SAR}=30\left(\mathrm{mmol} \mathrm{L}^{-1}\right)^{1 / 2}$ & $98.10 c$ & 36.02 \\
\hline LSD at $5 \%$ & 15.1 & \\
\hline
\end{tabular}

\section{Conclusion}

Aloe Vera (Aloe barbadeenis Mill) showed more salt tolerance at $4 \mathrm{dSm}^{-1}+13.5\left(\mathrm{mmol} \mathrm{L}^{-1}\right)^{1 / 2}$ than other saline- sodic combinations. Therefore, Aloe Vera (Aloe barbadeenis Mill) is recommended to be cultivated in salt- affected lands having salinity cum sodicity up to 4 $\mathrm{dSm}^{-1}+13.5\left(\mathrm{mmol} \mathrm{L}^{-1}\right)^{1 / 2}$.

\section{Acknowledgments}

None.

\section{Conflicts of interest}

Author declares that there is no conflicts of interest.

\section{References}

1. Khan MA, Duke NC. Halophytes- A resource for the future. Wetland Ecology and Management. 2001;6:455-456.

2. Cha-um S, Pokasombat Y, Kirdmanee C. Remediation of salt affected soil by gypsum and farmyard manure-Importance for the production of Jasmine rice. Aust J Crop Sci. 2011;5:458-465.

3. Essa TA. Effect of salinity stress on growth and nutrient composition of three soybean (Glycine max (L.) Merrill) cultivars. Journal of Agronomy \& Crop Science. 2002;188(2):86-93.
4. FAO. Global network on integrated soil management for sustainable use of salt-affected soils. FAO Land and Plant Nutrition Management Services, Rome, Italy; 2002.

5. Maghsoudi AM, Maghsoudi K. Salt stress effect on respiration and growth of germinated seeds of different wheat (Triticum sativum L.) cultivars. World J Agri Sci. 2008;4(3):351-358.

6. Moradi P, Zavareh M. Effects of salinity on germination and early seedling growth of chickpea (Cicer arietinum L.) cultivars. Intl J Farm \& Alli Sci. 2013;2(3):70-74.

7. Munns R. Genes and salt tolerance: bringing them together. New Phytol. $2005 ; 167: 645-663$

8. Nasser JY. Sholi. Effect of salt stress on seed germination, plant growth, photosynthesis and ion accumulation of four tomato cultivars. American Journal of Plant Physiology. 2012;7:269-275.

9. Zeinolabedin J. The Effects of Salt stress on plant growth. Technical Journal of Engineering and Applied Sciences (TJEAS). 2012;2(1):7-10.

10. Edris AE. Pharmaceutical and therapeutic potentials of essential oils and their individual volatile constituents: a review. Phytother Res. 2007;21:308-323.

11. Miguel MG. Antioxidant and anti-inflammatory activities of essential oils: a short review. Molecules. 2010;15:9252-9287.

12. Verpoorte R, Contin A, Memelink J. Biotechnology for the production of plant secondary metabolites. Phytochemistry. 2002;1: 13-25. 
13. Said-Al Ahl HAH, Omer EA. Medicinal and aromatic plants production under salt stress. Herba Polonica Journal. 2011;57:72-87.

14. Borsani O, Valpuesta V, Botella MA. Developing salt tolerant plants in a new century: A molecular biology approach. Plant Cell Tiss Org Cult. 2003;73:101-115.

15. Wang W, Vinocur B, Altman A. Plant responses to drought, salinity and extreme temperatures: towards genetic engineering for stress tolerance. Planta . 2003;218:1-14.

16. Sosa L, Llanes A, Reinoso H, et al. Osmotic and specifici on effect on the germination of Prosopis strombu lifera. Annals of Botany. 2005;96:261267.

17. FAO. Global network on integrated soil management for sustainable use of salt-affected soils. 2000

18. FAO. Land and Plant Nutrition Management Service. 2008.

19. Sultan M, N Zakir, MA Rabbani, et al. Genetic diversity of guar (Cyamopsis tetragonolobaL.) landraces from Pakistan based on RAPD markers. Pak J Bot. 2013;45(3):865-870.

20. Ashraf M, McNeilly T. Salinity tolerance in Brassica oilseeds. Critical Reviews in Plant Sciences. 2004;23:157-174.

21. Ashraf MY, Ashraf M, Sarwar G. Physiological approaches to improving plant salt tolerance, in Crops: Growth, Quality and Biotechnology. $R$ Dris Ed. 2005;1206-1227.

22. Rasool S, Hameed A, Azooz MM, et al.. Salt stress: causes, types and responses of plants. In: Ahmad P, Azooz MM. editors. Ecophysiology and Responses of Plants under Salt Stress, Springer. New York. 2013;124.

23. FAO. Land and plant nutrition management service. 2011

24. Taiz L, Zeiger E. Plant Physiology, 3rd edn. Sunderland: Sinauer Associates. 2003.

25. Flowers TJ. Improving crop salt tolerance. J Exp Bot. 2004;55:307-319.

26. Silva PO, Medina EF, Barros RS, et al. Germination of salt-stresses seeds as related to the ethylene biosynthesis ability in three Stylosanthes species. J Plant Physiol. 2014;171:14-22.
27. Mitsuya S, Kawasaki M, Taniguchi M, et al. Relationship between salinity-induced damages and aging in rice tissues. Plant Prod Sci. $2003 ; 6: 213-218$

28. Mitsuya S, Kawasaki M, Taniguchi M, et al. Light dependency of salinityinduced chloroplast degradation. Plant Prod Sci. 2003;6:219-223.

29. Ferdose J, Kawasaki M, Taniguchi M, et al. Differential sensitivity of rice cultivars to salinity and its relation to ion accumulation and root tip structure. Plant Prod Sci. 2009;12(4):453-461.

30. Munns R, James RA. Screening methods for salinity tolerance: a case study with tetraploid wheat. Plant Soil. 2033;253:201-218.

31. Eisa S, Hussin S, Geissler N,et al. .Effect of $\mathrm{NaCl}$ salinity on water relations, photosynthesis and chemical composition of Quinoa (Chenopodium quinoa Willd.) as a potential cash crop halophyte. Aust J Crop Sci. 2012;6:357-368.

32. Koyro HW, Geissler N, Seenivasan R, et al. Plant stress physiology physiological and biochemical strategies allowing to thrive under ionic stress. In: Pessarakli M (ed) Handbook of plant and crop stress, 3rd edn. CRC press, Taylor \& Francis Group. 2011;1051-1094.

33. Flexas J, Diaz EA, Galme's J, et al. Rapid variations of mesophyll conductance in response to changes in $\mathrm{CO} 2$ concentration around leaves. Plant Cell Environ. 2007;30:1284-1298.

34. Huchzermeyer B, Koyro HW. Salt and drought stress effects on photosynthesis. In: Pessarakli M, editor. Handbook of plant and crop stress, 2nd edn. Marcel Dekker Inc. 2005;751-778.

35. Munns R, James RA, Läuchli A. Approaches to increasing the salt tolerance of wheat and other cereals. J Exp Bot. 2006;57(5):1025-1043.

36. Bassil ES, SR Kaffka. Response of safflower (Carthamus tinctorius L.) to saline soils and irrigation II. Crop response to salinity. Agricultural Water Management . 2002;54(1):81-92.

37. FAO 2010. Food and agriculture organization. terrastat-land resource potential and constraints statistics at country and regionallevel. 2010.

38. Munns R. Comparative physiology of salt and water stress. Plant Cell and Environment. 2002:25:239-250. 